\title{
Hubungan Lama Berobat dan Keteraturan Berobat dengan Kadar HbA1c Pasien DM Tipe 2 di Poli Endokrin RSUP Prof. Dr. R. D. Kandou Manado
}

\author{
${ }^{1}$ Ridhel G. Sumakul \\ ${ }^{2}$ Karel Pandelaki \\ ${ }^{2}$ Frans E. N. Wantania
}

${ }^{1}$ Program Studi Pendidikan Dokter Fakultas Kedokteran Universitas Sam Ratulangi Manado

${ }^{2}$ Bagian Ilmu Penyakit Dalam Fakultas Kedokteran Universitas Sam Ratulangi Manado

Email: ridhelsumakul@gmail.com

\begin{abstract}
Type 2 diabetes mellitus (T2DM) is caused due to insulin target cells fail or are unable to respond to insulin normally (insulin resistance). Acute or chronic complications can occur in DM patients. Complications of DM can be prevented by optimal control of glycemia, in this case, the concentration of blood glucose and HbA1c. Regularity in medication consumption is important to prevent the occurence of diabetic complications. This study was aimed to determine the relationship of the duration and the regularity of diabetes treatment with HbA1c levels in T2DM patients at Endocrinology Polyclinic at Prof. Dr. R. D. Kandou Hospital Manado. This was a descriptive analytical study with a cross sectional design, using paients' medical record data. There were 60 samples obtained by using purposive sampling technique. The results of Chi-Square test showed that there was no corelation between duration of treatment and $\mathrm{HbA1c}$ level $(P=0.111)$ and there was no corelation between the regularity of treatment and HbA1c level $(P=0.224)$. Conclusion: There was no relationship between the duration and regularity of treatment with $\mathrm{HbA1c}$ levels of T2DM patients in the Endocrinology Polyclinic at Prof. Dr. R. D. Kandou Hospital Manado.
\end{abstract}

Keywords: T2DM, duration of treatment, regularity of treatment, HbA1c

\begin{abstract}
Abstrak: Diabetes melitus tipe 2 (DMT2) disebabkan karena sel-sel sasaran insulin gagal atau tak mampu merespon insulin secara normal (resistensi insulin). Komplikasi yang terjadi pada pasien DM dapat bersifat akut maupun kronis. Komplikasi DMT2 dapat dicegah dengan kontrol glikemia yang optimal yaitu terkendalinya konsentrasi glukosa dalam darah dan HbA1c. Keteraturan minum obat pada pasien DM merupakan hal penting dalam mencegah terjadinya komplikasi. Penelitian ini bertujuan untuk mengetahui hubungan lama berobat diabetes dan keteraturan berobat dengan kadar HbA1c pasien DMT2 di Poli Endokrin RSUP Prof . Dr. R. D. Kandou Manado. Jenis penelitian ialah deskriptif analitik dengan desain potong lintang, menggunakan data rekam medik. Teknik pengambilan sampel menggunakan purposive sampling dengan jumlah sampel sebanyak 60 pasien. Hasil uji Chi-Square menunjukkan tidak terdapat hubungan lama berobat DMT2 dengan kadar HbA1c $(P=0,111)$. Juga tidak terdapat hubungan keteraturan berobat dengan kadar HbA1c $(P=0,224)$. Simpulan: Tidak terdapat hubungan antara lama berobat dan keteraturan kunjungan berobat dengan kadar HbA1c pasien DM tipe 2 di Poli Endokrin RSUP Prof . Dr. R. D. Kandou Manado.
\end{abstract}

Kata kunci: DMT2, lama berobat, keteraturan berobat, HbA1c

Diabetes melitus (DM) merupakan suatu kelompok penyakit metabolik dengan karakteristik hiperglikemia yang terjadi karena kelainan sekresi insulin, kerja insulin, atau kedua-duanya. Hiperglikemia kronik pada DM berhubungan dengan 
kerusakan jangka panjang, disfungsi atau kegagalan beberapa organ tubuh, terutama mata, ginjal, saraf, jantung dan pembuluh darah. ${ }^{1}$ Diabetes melitus merupakan salah satu ancaman kesehatan manusia. Penyakit ini tidak menular, tetapi jumlah penyandangnya akan terus meningkat di masa mendatang. ${ }^{2}$

Diabetes melitus tipe 2 (DMT2) merupakan tipe diabetes yang lebih umum, lebih banyak penyandangnya dibandingkan diabetes melitus tipe 1 (DMT1). Penyebab DMT2 karena sel-sel sasaran insulin gagal atau tak mampu merespon insulin secara normal, keadaan ini disebut resistensi insulin. Pada penyandang DMT2 dapat juga terjadi produksi glukosa hepatik yang berlebihan namun tidak terjadi kerusakan sel-sel B Langerhans secara autoimun seperti DMT1. ${ }^{3}$ Data kejadian DM menurut International Diabetes Federation menyebutkan 415 juta orang menderita diabetes di dunia pada tahun 2015 dan pada tahun 2040 diperkirakan akan meningkat menjadi 642 juta orang. Menurut data studi populasi kasus yang dilakukan oleh IDF tahun 2015, Indonesia menempati urutan ketujuh sebagai negara dengan prevalensi DM terbanyak di dunia setelah China, India, USA, Brazil, Rusia, dan Mexico. ${ }^{4}$

Prevalensi DM di Indonesia untuk usia di atas 15 tahun sebesar 6,9\%. Prevalensi DM terdiagnosis di Indonesia sebesar $2,1 \%$. Prevalensi DM yang terdiagnosis dokter tertinggi terdapat di DI Yogyakarta (2,6\%), DKI Jakarta (2,5\%), Sulawesi Utara (2,4\%), dan Kalimantan Timur $(2,3 \%)$. Hal ini menunjukkan bahwa Sulawesi Utara merupakan salah satu provinsi dengan angka prevalensi DM yang tertinggi di Indonesia. ${ }^{5}$ Hasil Riskesdas 2013, prevalensi DM berdasarkan wawancara terjadi peningkatan dari $1,1 \%$ tahun 2007 menjadi 2,1\% tahun 2013 dan yang terdiagnosis oleh dokter sebanyak $1,5 \%$. Di Sulawesi Utara tahun 2013 terdapat 2,4\% penyandang DM. Provinsi Sulawesi Utara merupakan salah satu provinsi dengan jumlah kasus DM yang cukup tinggi. Kejadian DM yang diperoleh dari data Dinas Kesehatan Provinsi Sulawesi Utara, menunjukkan bahwa jumlah kasus DM terus meningkat. Pada tahun 2015 jumlah penyandang DM sebanyak 3652 kasus dan mengalami peningkatan pada tahun 2016 dengan jumlah 5083 kasus. Data yang diperoleh dari Dinas Kesehatan Kota Manado, menyatakan bahwa jumlah kasus DM pada tahun 2015 yaitu 2756 kasus dan meningkat pada tahun 2016 dengan jumlah 3496 kasus. ${ }^{6,7}$

Menurut Perkumpulan Endokrinologi Indonesia (Perkeni), terdapat empat pilar yang diperlukan untuk menunjang peningkatan kualitas hidup penyandang DM yang sangat penting dalam pengelolaan DM, yaitu edukasi, terapi nutrisi medis, latihan jasmani, dan farmakologis. ${ }^{2}$ Komplikasi yang didapat pada seseorang karena lamanya DM yang diderita bersifat akut maupun kronis. Komplikasi tersebut dapat menyebabkan pendeknya rentang hidup seseorang, keterbatasan diri, dan meningkatnya beban ekonomi bagi penyandang dan keluarganya, sehingga sangat memengaruhi kualitas hidup penyandang bila tidak mendapatkan perawatan yang tepat. ${ }^{8}$

Bukti-bukti menunjukkan bahwa komplikasi DM dapat dicegah dengan kontrol glikemia yang optimal. Kontrol glikemia yang optimal yaitu terkendalinya konsentrasi glukosa dalam darah, HbA1c (hemoglobin terglikosilasi), kolesterol, trigliserida, status dan tekanan darah. ${ }^{9}$ HbA1c merupakan komponen minor dari hemoglobin yang berikatan dengan glukosa. ${ }^{10}$

Pengukuran $\mathrm{HbA1c}$ merupakan cara yang paling akurat untuk menentukan tingginya kadar gula darah selama 2-3 bulan terakhir. HbA1c juga merupakan pemeriksaan terbaik untuk menilai risiko terhadap kerusakan jaringan yang disebabkan oleh tingginya kadar gula darah. ${ }^{11}$

Penelitian yang dilakukan di Jordan pada tahun 2009 menyatakan dari 337 pasien DM yang teratur untuk mengontrol gula darah 3 bulan sekali dengan pemeriksaan $\mathrm{HbA} 1 \mathrm{c}$ terdapat $56,1 \%$. pasien memiliki HbA1c kurang dari 7,0\%; sebanyak $23,7 \%$ pasien memiliki HbA1c antara 7$7,9 \%$; dan sebanyak $20,2 \%$ pasien memiliki HbA1c lebih dari $8 \% .{ }^{12}$ Hasil penelitian 
tersebut sejalan dengan penelitian yang dilakukan di Spanyol pada tahun 2014 yang melaporkan bahwa dari 5.382 pasien DM yang telah memeriksakan HbA1c secara teratur 3 bulan sekali sebanyak $51,4 \%$ pasien memiliki kadar HbA1c kurang dari $7 \%$ dan sebanyak 48,6\% memiliki kadar HbA1c lebih atau sama dengan $7 \% .^{13}$ Kedua penelitian ini mengasumsikan bahwa pasien DMT2 yang melakukan pemeriksaan $\mathrm{HbA1c}$ secara teratur 3 bulan sekali memiliki kadar HbA1c terkontrol dengan baik dan gula darah membaik jika secara teratur memeriksakan $\mathrm{HbA} 1 \mathrm{c}$.

Penelitian ini bertujuan untuk mengetahui hubungan lama berobat dan keteraturan berobat dengan kadar HbA1c pasien DMT2 di Poli Endokrin RSUP Prof. Dr. R. D. Kandou Manado.

\section{METODE PENELITIAN}

Jenis penelitian ini ialah deskriptif analitik dengan desain potong lintang, menggunakan data rekam medik pasien DMT2 periode 2017. Penelitian ini dilakukan di Poli Endokrin RSUP Prof. Dr. R. D. Kandou Manado pada bulan Oktober sampai dengan Desember 2018. Sampel penelitian diperoleh menggunakan metode purposive sampling yaitu sampel diambil dengan cara menetapkan ciri-ciri khusus yang sesuai dengan tujuan penelitian.

\section{HASIL PENELITIAN}

Berdasarkan penelitian yang dilakukan di RSUP Prof. Dr. R. D. Kandou Manado khususnya di Poli Endokrin didapatkan data rekam medik pasien DMT2 berjumlah 323 rekam medik pasien. Dari hasil rekam medik tersebut, yang didapatkan oleh petugas rekam medik hanya sekitar 162 rekam medik. Jumlah sampel yang memenuhi kriteria inklusi didapatkan dengan jumlah sampel sebanyak 60 sampel rekam medik.

Hasil analisis univariat memperlihatkan pada distribusi pasien berdasarkan jenis kelamin, yang memiliki jenis kelamin terbanyak yaitu jenis kelamin perempuan (Tabel 1) sebanyak 35 pasien $(58,3, \%)$ dan pasien jenis kelamin laki-laki sebanyak 25 pasien $(41,7 \%)$. Distribusi pasien berdasar- kan usia mendapatkan kelompok usia 61-70 tahun yang terbanyak (Tabel 2) yaitu 25 pasien $(41,7 \%)$ dan yang paling sedikit pada kelompok usia 30-40 tahun yaitu 2 pasien $(3,3 \%)$.

Tabel 1. Distribusi pasien berdasarkan jenis kelamin

\begin{tabular}{lcc}
\hline $\begin{array}{c}\text { Jenis } \\
\text { kelamin }\end{array}$ & n & \% \\
\hline Laki-laki & 25 & 41,7 \\
Perempuan & 35 & 58,3 \\
Total & 60 & 100 \\
\hline
\end{tabular}

Tabel 2. Distribusi pasien berdasarkan usia

\begin{tabular}{ccc}
\hline $\begin{array}{c}\text { Usia } \\
\text { (tahun) }\end{array}$ & $\mathbf{n}$ & $\mathbf{\%}$ \\
\hline $30-40$ & 2 & 3,3 \\
$41-50$ & 8 & 13,3 \\
$51-60$ & 14 & 23,3 \\
$61-70$ & 25 & 41,7 \\
$71-80$ & 11 & 18,3 \\
Total & 60 & 100 \\
\hline
\end{tabular}

Distribusi pasien berdasarkan lama berobat diabetes mendapatkan indikator lama berobat diabetes jangka pendek yang terbanyak (Tabel 3) yaitu 48 pasien $(80 \%)$ dan yang paling sedikit ialah lama berobat jangka panjang yaitu 12 pasien (20\%).

Tabel 3. Distribusi pasien berdasarkan lama berobat

\begin{tabular}{lcc}
\hline Lama berobat & n & \% \\
\hline Jangka pendek & 48 & 80 \\
Jangka panjang & 12 & 20 \\
Total & 60 & 100 \\
\hline
\end{tabular}

Distribusi pasien berdasarkan keteraturan berobat mendapatkan indikator keteraturan berobat tidak teratur yang terbanyak (Tabel 4) yaitu 42 pasien $(70 \%)$ dan keteraturan berobat teratur yang paling sedikit yaitu 18 pasien (30\%). Distribusi pasien berdasarkan HbA1c mendapatkan indikator HbA1c tidak terkontrol yang terbanyak (Tabel 5) yaitu 37 pasien $(61,7 \%)$ dan yang paling sedikit ialah HbA1c terkontrol yaitu 23 pasien $(38,3 \%)$. 
Tabel 4. Distribusi pasien berdasarkan keteraturan berobat

\begin{tabular}{lcc}
\hline $\begin{array}{l}\text { Keteraturan } \\
\text { berobat }\end{array}$ & n & \% \\
\hline Tidak teratur & 42 & 70 \\
Teratur & 18 & 30 \\
Total & 60 & 100 \\
\hline
\end{tabular}

Tabel 5. Distribusi pasien berdasarkan $\mathrm{HbA1c}$

\begin{tabular}{lcc}
\hline HbA1c & n & \% \\
\hline Terkontrol & 23 & 38,3 \\
Tidak terkontrol & 37 & 61,7 \\
Total & 60 & 100 \\
\hline
\end{tabular}

Hasil analisis bivariat terhadap hubungan antara lama berobat dengan kadar HbA1c pasien DMT2 di Poli Endokrin RSUP Prof. Dr. R. D. Kandou Manado (Tabel 6) memperlihatkan bahwa pasien yang memiliki indikator lama berobat jangka panjang dengan $\mathrm{HbA1c}$ terkontrol sebanyak 7 pasien $(58,3 \%)$ dan lama berobat jangka panjang dengan $\mathrm{HbA1c}$ tidak terkontrol sebanyak 5 pasien $(41,7 \%)$; lama berobat jangka pendek dengan HbA1c terkontrol sebanyak 16 pasien $(33,3 \%)$, dan lama berobat jangka pendek dengan $\mathrm{HbA} 1 \mathrm{c}$ tidak terkontrol sebanyak 32 pasien
(66,7\%). Hasil uji Chi Square mendapatkan nilai $P=0,111 \quad(<0,05)$ yang menunjukkan bahwa tidak terdapat hubungan bermakna antara lama berobat dengan kadar HbA1c pasien DMT2 di poli Endokrin RSUP Prof. Dr. R. D. Kandou Manado.

Hasil analisis bivariat terhadap hubungan antara keteraturan berobat dengan kadar HbA1c pasien DMT2 di Poli Endokrin RSUP Prof. Dr. R. D. Kandou Manado (Tabel 7) memperlihatkan bahwa pasien yang memiliki indikator keteraturan berobat teratur dengan $\mathrm{HbA} 1 \mathrm{c}$ terkontrol sebanyak 9 pasien $(50 \%)$ dan keteraturan berobat teratur dengan HbA1c tidak terkontrol sebanyak 9 pasien $(50 \%)$; keteraturan berobat tidak teratur dengan HbA1c terkontrol sebanyak 14 pasien $(33,3 \%)$ dan keteraturan berobat tidak teratur dengan $\mathrm{HbA1c}$ tidak terkontrol sebanyak 28 pasien $(66,7 \%)$. Hasil uji $C h i$ Square mendapatkan nilai $P=0,224(<0,05)$ yang menunjukkan bahwa tidak terdapat hubungan bermakna antara keteraturan berobat dengan kadar HbA1c pada pasien DMT2 di Poli Endoktrin RSUP Prof. Dr. R. D. Kandou Manado.

Tabel 6. Hubungan antara Lama Berobat dengan Kadar HbA1c pasien DMT2 di Poli Endokrin RSUP Prof. Dr. R. D. Kandou Manado

\begin{tabular}{lcccccccc}
\hline \multirow{1}{*}{ Lama berobat } & \multicolumn{9}{c}{ HbA1c } \\
& \multicolumn{2}{c}{ Terkontrol } & \multicolumn{2}{c}{ Tidak terkontrol } & Total & \multirow{2}{*}{$\boldsymbol{P}^{*}$} & OR \\
& $\mathrm{n}$ & $\%$ & $\mathrm{n}$ & $\%$ & $\mathrm{n}$ & $\%$ & & \\
\hline Jangka panjang & 7 & 58,3 & 5 & 41,7 & 12 & 100 & 0,111 & 2,800 \\
Jangka pendek & 16 & 33,3 & 32 & 66,7 & 48 & 100 & & \\
Total & 23 & 38,3 & 37 & 61,7 & 60 & 100 & & \\
\hline
\end{tabular}

*Uji Chi Square

Tabel 7. Hubungan antara keteraturan berobat dengan kadar HbA1c pasien DMT2 di Poli Endokrin RSUP Prof. Dr. R. D. Kandou Manado

\begin{tabular}{lcccccccc}
\hline \multirow{2}{*}{$\begin{array}{c}\text { Keteraturan } \\
\text { berobat }\end{array}$} & \multicolumn{9}{c}{ Terkontrol } & \multicolumn{2}{c}{ Tidak terkontrol } & \multicolumn{2}{c}{ Total } & \multirow{2}{*}{ OR } & OR \\
& $\mathrm{n}$ & $\%$ & $\mathrm{n}$ & $\%$ & $\mathrm{n}$ & $\%$ & & \\
\hline Teratur & 9 & 50 & 9 & 50 & 18 & 100 & 0,224 & 2,000 \\
Tidak teratur & 14 & 33,3 & 28 & 66,7 & 42 & 100 & & \\
Total & 23 & 38,3 & 37 & 61,7 & 60 & 100 & & \\
\hline *Uji Chi Square & & & & & & & &
\end{tabular}




\section{BAHASAN}

Jumlah sampel dalam penelitian ini ialah sebanyak 60 pasien. Jenis kelamin yang memiliki distribusi terbanyak yaitu perempuan $(58,3 \%)$ dibandingkan jenis kelamin laki-laki (41,7\%). Perempuan lebih rentan menyandang DMT2 dibandingkan laki-laki karena aktivitas yang kurang dan gaya hidup sehari-hari. ${ }^{14}$

Berdasarkan kelompok usia, pasien dengan kelompok usia 61-70 tahun yang terbanyak $(41,7 \%)$ dan yang paling sedikit ialah kelompok usia 30-40 tahun (2\%). Peningkatan DMT2 sangat erat kaitannya dengan peningkatan usia karena lebih dari $50 \%$ penyandang DM terjadi pada kelompok usia lebih dari 60 tahun. ${ }^{15} \mathrm{Hal}$ ini dapat dilihat dari hasil penelitian yaitu mayoritas yang menyandang DM merupakan usia lansia (61-70 tahun). Pada orang yang sudah berusia lanjut, fungsi organ tubuh semakin menurun, mengakibatkan menurunnya fungsi endokrin pankreas untuk memroduksi insulin. ${ }^{16}$ Penelitian lain menyebutkan bahwa kelompok usia 41-64 tahun memiliki risiko untuk menyandang DM 3,3 kali lebih besar dibanding dengan kelompok usia 25-40 tahun. ${ }^{17}$

Hasil uji Chi Square terhadap hubungan antara lama berobat dengan kadar HbA1c pasien DMT2 di Poli Endokrin mendapatkan nilai $P=0,111(<0,05)$ dengan nilai OR 2,8 yang menyatakan bahwa pasien yang telah berobat jangka pendek memiliki risiko HbA1c tidak terkontrol 2,8 kali dibandingkan dengan pasien yang lama berobat jangka panjang. Tidak terdapat hubungan bermakna antara lama berobat dengan kadar HbA1c pasien DMT2. Sampai saat ini belum didapatkan penelitian yang melaporkan hubungan antara lama berobat dengan kadar $\mathrm{HbA1c}$; yang dilaporkan ialah lama menyandang DM dengan peningkatan kadar $\mathrm{HbA} 1 \mathrm{c}$ dan kadar glukosa plasma yang ternyata terdapat hubungan. ${ }^{18}$ Terdapat beberapa hal yang menyebabkan glukosa darah naik, yaitu kurangnya aktivitas fisik, bertambahnya jumlah makanan yang dikonsumsi, dan peningkatan stres. ${ }^{19}$

Aktivitas fisik adalah setiap gerakan tubuh dengan tujuan meningkatkan dan mengeluarkan tenaga atau energi. Aktivitas fisik berperan dalam mengontrol gula darah tubuh dengan cara mengubah glukosa menjadi energi. ${ }^{20}$ Aktivitas fisik yang dilakukan oleh seseorang akan memengaruhi kadar glukosa darahnya. Penggunaan glukosa oleh otot akan meningkat saat seseorang melakukan aktivitas fisik yang tinggi. Hal tersebut disebabkan glukosa endogen akan ditingkatkan untuk menjaga agar kadar glukosa di dalam darah tetap seimbang. Pada keadan normal, keseimbangan kadar glukosa darah tersebut dapat dicapai oleh berbagai mekanisme dalam sistem saraf, regulasi glukosa, dan keadaan hormonal. ${ }^{21}$ Teori lain menyebutkan bahwa aktifitas fisik secara langsung berhubungan dengan kecepatan pemulihan glukosa darah otot. Saat aktivitas fisik dilakukan, otot-otot tubuh bereaksi dengan menggunakan glukosa yang disimpannya sehingga simpanan glukosa berkurang. Dalam keadaan tersebut terjadi reaksi otot yaitu otot akan mengambil glukosa darah sehingga kadar glukosa darah menurun yang dapat meningkatkan kontrol glukosa darah. ${ }^{22}$

Pola makan juga berperan penting dalam mengatur kadar glukosa darah. Kebiasaan mengomsumsi makanan/ minuman manis berpotensi meningkatkan kadar glukosa dalam darah. Hal itu karena makanan/minuman manis umumnya mengandung gula pasir sehingga gula ini langsung masuk ke aliran darah. Mengonsumsi makanan berlemak akan semakin meningkatkan risiko terkena DM. Kandungan lemak dalam makanan akan meningkatkan kadar lemak secara spontan di dalam darah yang akhirnya menghambat predaran dan mempersempit pembuluh darah. Selain itu, kadar lemak tinggi di dalam darah akan menurunkan daya guna insulin. ${ }^{23}$

Penelitian Beardlsey dan Goldstein ${ }^{24}$ mendapatkan tingginya tingkat stres dapat dihubungkan dengan buruknya regulasi gula darah. Pada kondisi depresi, tubuh akan mengeluarkan hormon-hormon stres yang akan memengaruhi peningkatan kadar glukosa darah (HbA1c). Pemeriksaan 
HbA1c merupakan tolak ukur paling tepat dalam pengendalian DM. HbA1c dapat digunakan sebagai tes diagnostik untuk DM yang menunjukkan jaminan tes yang berkualitas dan sesuai dengan standar kriteria nilai-nilai rujukan internasional. ${ }^{25}$ Pemeriksaan HbA1c merupakan baku emas dalam pengukuran kadar glikemik, bahkan pada orang non-diabetes yang terkait dengan kinerja kognitif dan volum otak. ${ }^{25}$ Kontrol gula darah merupakan dasar dari pengelolaan $\mathrm{DM}^{27}$

Hasil uji Chi Square terhadap hubungan antara keteraturan berobat dengan kadar HbA1c pasien DMT2 di Poli Endokrin mendapatkan nilai $P=0,224(<0,05)$ dengan besar nilai OR 2 yang menyatakan bahwa pasien yang tidak berobat dengan eratur memiliki risiko $\mathrm{HbA} 1 \mathrm{c}$ tidak terkontrol 2 kali dibandingkan dengan pasien yang berobat teratur. Hal ini menunjukkan bahwa tidak terdapat hubungan bermakna antara keteraturan berobat dengan kadar HbA1c pasien DMT2. Penyebabnya yaitu pasien yang tidak disiplin dalam mengonsumsi obat. Hasil penelitian ini sejalan dengan penelitian oleh Adikusuma ${ }^{28}$ yang mendapatkan tingkat kepatuhan pasien DMT2 yang tergolong patuh $50 \%$ dan yang tidak patuh $50 \%$ serta adanya korelasi negatif antara kepatuhan pengobatan pasien DMT2 terhadap kadar HbA1c ( $\mathrm{r}=0,081$; $P=0,619)$. Tidak terdapat hubungan antara tingkat kepatuhan minum obat antidiabetik oral terhadap kadar HbA1c. ${ }^{28}$ Kepatuhan memegang peranan penting dalam mencapai target terapi terutama penyakit kronis seperti diabetes melitus. Rendahnya kepatuhan pasien terhadap pengobatan DM merupakan salah satu penyebab rendahnya kontrol kadar glukosa darah. Tingkat kepatuhan penyandang DM mengonsumsi obat merupakan salah satu faktor yang menentukan keberhasilan terapi, terutama untuk penyakit kronis seperti diabetes melitus. Faktor penghalang yang memengaruhi kepatuhan pasien yaitu lamanya terapi, kompleksitas rejimen, komunikasi yang kurang baik antara pasien dan tenaga kesehatan, kurangnya informasi, persepsi manfaat, keamanan, efek samping, biaya pengobatan, dan faktor psikologis. ${ }^{29}$

Untuk kontrol glikemik, salah satunya dapat dilakukan dengan pemeriksaan hemoglobin glikosilat (HbA1c) yang dapat memberikan gambaran kadar glukosa darah sehari-hari pasien DM. HbA1c merupakan ikatan molekul glukosa pada hemoglobin secara non-enzimatik melalui proses glikasi pasca translasi. Hemoglobin yang terglikasi terlihat dalam beberapa asam amino $\mathrm{HbA}$ yang terdiri dari $\mathrm{HbA} 1 \mathrm{a}, \mathrm{HbA} 1 \mathrm{~b}$, dan HbA1c. Komponen yang terpenting dari glikasi hemoglobin tersebut pada penyakit DM ialah HbA1c. Pemeriksaan HbA1c digunakan sebagai patokan utama untuk pengendalian penyakit DM karena HbA1c dapat mengambarkan kadar glukosa darah dalam rentang 1-3 bulan sehubungan dengan usia sel darah merah yang terikat oleh molekul glukosa ialah 120 hari. $^{30}$ Faktor-faktor yang dapat memengaruhi kadar HbA1c di antaranya ialah gangguan hemoglobin. Gangguan hemoglobin dapat meningkatkan atau menurunkan kadar HbA1c, seperti hemoglobinopati, HbF, atau methemoglobin glikasi. Hal-hal yang dapat menurunkan HbAlc diantaranya ialah alkoholisme, gagal ginjal kronik, dan penurunan $\mathrm{pH}$ intra eritrosit sedangkan aspirin, vitamin $\mathrm{C}$, vitamin $\mathrm{E}$ dan peningkatan $\mathrm{pH}$ intra eritrosit dapat meningkatkan HbA1c. Destruksi eritrosi dengan splenektomi dapat meningkatkan HbA1c sedangkan splenomegali dan obat anti rematik dapat menurunkan HbA1c. Demikian pula keadaan hiperbilirubinemia dapat meningkatkan HbA1c. ${ }^{31}$

\section{SIMPULAN}

Berdasarkan hasil penelitian ini dapat disimpulkan bahwa tidak terdapat hubungan antara lama berobat dan keteraturan berobat dengan kadar HbA1c pada pasien DM Tipe 2 di Poli Endokrin RSUP Prof. Dr. R. D. Kandou Manado.

\section{DAFTAR PUSTAKA}

1. Purnasari D. Diagnosis dan klasifikasi diabetes melitus. In: Sudoyo AW, Setiohadi B, Alwi I, Simadibrata M, Setiati S, editors. Buku Ajar Ilmu 
Penyakit Dalam, Jilid III (5th ed). Jakarta: Interna Publishing, 2009.

2. Perkumpulan Endokrinologi Indonesia (Perkeni). Konsensus pengelolaan diabetes mellitus tipe 2 di Indonesia. Jakarta; Perkeni, 2015.

3. Suyono S. Diabetes melitus di Indonesia. In: Setiati S, Alwi I, Sudoyo AW, Marcellus SK, Setiyohadi B, Syam AF, editors. Ilmu Penyakit Dalam. (6th ed). Jakarta: InternaPublishing, 2014; p. 2315-22.

4. Ary. Januar. Pranata P. Hubungan diabetes dengan perilaku perawatan diri pada penyandang diabetes mellitus tipe 2 di wilayah kerja Puskesmas Rambipuji Kabupaten Jember [Skripsi]. Jember: Program Studi Ilmu Keperawatan Universitas Jember; 2016.

5. Kementerian Kesehatan RI. Riset Kesehatan dasar. Jakarta: Kementerian Kesehatan RI. Badan Penelitian dan Pengembangan Kesehatan Kemenkes RI, 2013.

6. Dinas Kesehatan Kota Manado. Profil Kesehatan Kota Manado. Manado, 2016.

7. Dinas Kesehatan Provinsi Sulut. Profil Kesehatan Provinsi Sulut Tahun 2016. Sulawesi Utara, 2016.

8. Zimmet P. Preventing diabetic complication: a primary care prospective. Diabetes Res Clin Pract. 2009;84:107-16.

9. Utomo MRS, Wungouw H, Marunduh S. Kadar HbAlc pada pasien diabetes melitus tipe 2 di Puskesmas Bahu Kecamatan Malalayang Kota Manado. eBm. 2015;3(1).

10. Arifatunhidjah. Hubungan kadar $\mathrm{HbAlc}$ dan gula darah pada pasien diabetes melitus tipe 2 di Rumah Sakit Umum Ambarawa. Semarang: Universitas Muhammadiyah; 2017.

11. Guntur, Ongkowijaya J, Wantania FE. Hubungan asam urat dan $\mathrm{HbAlc}$ pada penderita diabetes melitus tipe 2 yang dirawat inap di RSUP Prof. Dr. R. D. Kandou. eCl. 2016;4(2).

12. Al Omari M, Khader Y, Dauod a S, AlAkour N, Khassawneh a $\mathbf{H}$, AlAshker E, et al. Glycaemic control among patients with type 2 diabetes mellitus treated in primary care setting in Jordan. Prim Care Diabetes. 2009;3(3):173-9.

13. Pérez A, Mediavilla JJ, Miñambres I,
González-Segura D. Glycemic control in patients with type 2 diabetes mellitus in Spain. Rev Clín Esp. 2014;214(8):429-36.

14. Sugondo S. Penatalaksanaan Diabetes secara Terpadu. Jakarta: FKUI publisher, 2007.

15. Goldstein BJ. Type 2 Diabetes: Principles and Practice (2nd ed). New York: Informa Healthcare, 2007.

16. Waspadji S. Komplikasi Kronis Diabetes: Mekanisme, Diagnosis dan Strategi Pengobatan (4th ed). Jakarta, Indonesia: Penerbit FK UI; 2006.

17. Rahajeng E. Pengaruh konsumsi kopi terhadap kejadian diabetes mellitus tipe 2. Gizi Indonesia; 2010;33(2):82-95.

18. Goud M, Nayal B, Devi S, Sathista T, Shivashanker S, Devaki R. Relation of caluculated $\mathrm{HbAlc}$ with fasting plasma glucose and duration of diabetes. IJABPT. 2011;2:58-61.

19. Berkat, Saraswati LD, Muniroh M. Faktorfaktor yang berhubungan dengan kadar gula darah pada penderita diabetes melitus tipe 2 di RSUD K. R. M. T Wongsonegoro Semarang. Jurnal Kesehatan Masyarakat. 2018;6(1):.200-6.

20. Direktorat pengendalian penyakit tidak menular direktorat jendral pengendalian penyakit dan penyehatan lingkungan (DITJEN PP \& PL) Departemen Kesehatan RI. Petunjuk teknis pengukuran faktor resiko diabetes mellitus, 2008.

21. Kroneberg H. Williams Textbook of Endocrinology. Philadelphia: Saunders Elsevier publishing, 2009.

22. Barnes DE. Program Olahraga Diabetes. Yogyakarta: Citra Aji Pramana, 2011.

23. Marewa WL. Kencing Manis (Diabetes Melitus) di Sulawesi Selatan. Jakarta Yayasan Pustaka Obor Indonesia, 2015.

24. Beardsley G, Goldstein MG. Psychological factors affecting physical condition. Endocrine disease literature review. Psychosomatics. 1993;34:12-9.

25. WHO Use of glycated haemoglobin (HbA1c) in the diagnosis of diabetes mellitus: report of a WHO consultation. World Health Organization, 2011.

26. Rochmah S, Hanmurti K. Demensia. In: Sudoyo Aru W, Setiyohadi B, Alwi I, Simadibrata M, Setiati S, editors. Buku Ajar Ilmu Penyakit Dalam Jilid III (5th 
ed). Jakarta: Interna Publishing, 2009.

27. Herman WH. Evidence-based diabetes care. Clinical Diabetes. 2002;20(1):22-3.

28. Adikusuma W. Hubungan tingkat kepatuhan minum obat antidiabetik oral terhadap kadar hemoglobin terglikasi (HbA1c) pada pasien diabetes millitus tipe 2 . Mataram: Fakultas Ilmu Kesehatan Universitas Muhamadiyah; 2017.

29. Aronson JK. Compliance, concordance, adherence. $\mathrm{Br} \mathrm{J}$ Clin Pharmacol. 2007;63(4):383-4.

30. Chugh S. Jaypee Gold Standard Mini Atlas Series Diabetes. I. India: Jaypee Brothers Medical Publishers, 2011.

31. Tanhardjo J, Pinzon RT, Sari LK. Perbandingan rerata kadar Hba1c pada pasien diabetes mellitus dengan neuropati dan tanpa neuropati sensori motor. BIKDW. 2016;1(2)L:127-36. 